\title{
Being different and the same? The paradoxes of 'tailoring' in education quasi - markets
}

\author{
Glenn C. Savage
}

Abstract: In Australia, market-based education policies promote the notion that government schools should flexibly tailor secondary education to the needs of young people and their local communities. Far from offering a "one size fits all" system, policies seek to enable clients (parents, students) to exercise freedom of choice in quasi-markets that offer different educational products to different individuals. The intended effect is a kind of bespoke education tailoring, whereby schools operate as flexible service providers, adapting to the needs and desires of local markets. In this paper, I analyse the policy turn towards market tailoring as part of broader shifts towards advanced liberal governance in education. Following this, I feature interviews with educators in two socially disparate government secondary schools in the Australian city of Melbourne. In doing so, I analyse the extent to which each school tailors its marketing practices to its local community. These interviews suggest inherent contradictions emerge when tailoring is attempted in a hierarchical market with normative and rigid indicators of 'brand value'. Schools are caught, I argue, between paradoxical demands, requiring them to be simultaneously different and the same.

Key words: education policy, marketisation, tailoring, governance, secondary schooling

\section{Introduction}

In Australia and other Western liberal democracies, market-based education policies promote the notion that government secondary schools should flexibly tailor education to the needs of young people and their local communities. Far from offering a "one size fits all" system, policies seek to enable clients (parents, students) to exercise freedom of choice in quasi-markets that offer different educational products to different individuals (Gewirtz, 2002; Campbell, Proctor \& Sherrington, 2009). Schools are encouraged, in this climate, to adapt, specialise and carve distinctive market niches (Ken- 
way $\&$ Bullen, 2001; Doherty, 2007). The creation of a mixed-market is supposed to promote productive competition between schools and allow clients to "personalise" (Peters, 2010) their educational trajectories. Responsiveness to user-demand, it seems, is the new policy mantra. In Australia, a broad suite of federal and state reforms are being instituted which seek to increase the capacities of schools to tailor curriculum provision, promote locally responsive forms of innovation and allow school principals greater flexibility over the management of staff and finances (see Dixon, 2011; COAG, 2012). The intended effect is a kind of bespoke education tailoring, whereby schools operate as flexible service providers, adapting to the needs and desires of local markets.

In this paper, I analyse policies linked to market tailoring as part of shifts towards "advanced liberal governance" (Rose, 1996, 1999a; Dean, 1999, 2010). Specifically, I argue that tailoring policies are underpinned by two central features of advanced liberalism: the quasi-marketisation of public services; and community governance models. Following this, I feature interviews with educators in two socially disparate government secondary schools in the Australian city of Melbourne: Bridgeway High and Clapton High $^{1}$. In doing so, I analyse the extent to which each school tailors its marketing practices to its local community. These interviews reveal a host of tensions and conflicts, as whilst educators at both schools were unanimous in the view that their school tailored its marketing to its local community, contradictory evidence emerged which suggests school managers at both schools were attempting to market their school in very similar ways by promoting normative images associated with academic excellence and by emulating the marketing practices of exclusive private schools. These normative images glossed over local differences and implicated both schools in practices which run counter to the logics of market tailoring. In conclusion, I argue that inherent contradictions emerge when tailoring is attempted in a hierarchical market with normative and rigid indicators of 'brand value'. Schools are caught, I argue, between paradoxical demands, requiring them to be simultaneously different and the same.

\section{Tailoring in Education Quasi - markets: Governing the 'Advanced liberal' Way}

The policy turn towards 'market tailoring' in education can be analysed as part of a broader shift towards advanced liberal governance: a form of governance that frames markets as the most effective means for governing and

1 The names of both schools and all participants have been anonymised. 
optimising human life and capital (Rose, 1996, 1999a; Dean, 1999, 2010). Advanced liberalism is one of a cluster of related terms used by researchers who adopt a "governmentality ethos" (Miller \& Rose, 2008, p. 13) when analysing the political present. Other popular terms in governmentality and beyond include neoliberalism (Marginson, 1997; Ong, 2006; Peters, 2011; Rizvi \& Lingard, 2010; Lipman, 2011; Ball, 2012) and the Third Way (Giddens, 1998; Rose, 2000; Gewirtz, 2002). There is also a frequent blurring of these terms, with the political rationalities and technologies termed "advanced liberal" by theorists like Miller and Rose (Rose, 1996, 1999a; Miller \& Rose, 2008) being very similar to those described as "neoliberal" by others (Ong, 2006; Peters, 2011; Rizvi \& Lingard, 2010; Ball, 2012). This mash of terminology can be clarified to some extent by suggesting advanced liberalism denotes the broader yet coherent assemblage of political rationalities and technologies which define the political present (the overarching category), whereas neoliberalism and the Third Way represent sub-variants within this broader polymorphic field (Rose, 1996, pp. 60-61; Dean, 1999, pp. 149-150; Dean, 2010, pp. 10-11). This distinction is useful to explain how different sub-variants of advanced liberalism coexist and inter-mesh (Dean, 1999, p. 150). By describing the political present as "advanced liberal", therefore, one can identify differences of approach whilst acknowledging a shared family resemblance. This is useful in systems like Australia and England, where state and federal education policies reflect an uneasy fusion of neoliberal, Third Way and older social democratic approaches (Savage, 2011).

Advanced liberalism is generally understood to have emerged through a series of governmental shifts, particularly from the 1970s onwards, in response to the perceived ineffectiveness of post-war Keynesianism and forms of "welfare state" governance (Foucault, 2008; Miller \& Rose, 2008, p. 18). According to Foucault (2008), these shifts proffered a distinct form of governmental reason based on the economy, the market, human capital and an entrepreneurial vision of the individual (pp. 215-290). Building on Foucault's theories, Miller and Rose (2008) define the core features of advanced liberalism as:

... an extension of rationalities and technologies of markets to previously exempt zones such as health and education... the deployment of new technologies of governing from a centre through powerful means of governing at a distance... a new conception of the subjects to be governed: that these would be autonomous and responsible individuals, freely choosing how to behave and act... [and] the emergence of novel strategies of 
activation, in policies for the government of economic life and of social security. (p. 18)

Policies which promote education tailoring are underpinned, I believe, by two central features of advanced liberalism ${ }^{2}$. The first is the quasi-marketisation of public services. Over the past three decades, for example, education systems across the world have experienced a broad-scale reconfiguration in line with market-based forms of governance (Rose, 1996; Ball, 2006; Ong, 2006; Miller \& Rose, 2008; Peters, 2010). Rose (1996) describes these shifts in terms of "a new relation between expertise and politics" (p. 54), whereby previous welfarist modes of governance, based on truth claims with a basis in the social sciences, were gradually replaced by modes of governance based on truth claims from the 'grey sciences' of management and economics (p. 54). Ong (2006) and Peters (2010) make similar arguments in analysing the rise of neoliberalism. Peters (2010) argues that in the 1980s, "a distinctive strand of neoliberalism emerged as the dominant paradigm of public policy", central to which was either an abolishment or drastic re-writing of welfarism in favour of "market solutions" at "all levels" of government (p. 370). Ong (2006) suggests that market logic is the defining feature of "neoliberal governmentality" (p. 4), which has resulted from "the infiltration of market-driven truths and calculations into the domain of politics" (p. 4).

In Western nations, the marketisation of government education systems has resulted from a gradual series of interventions by governments which have recast education in line with market modes of operation (Marginson, 1997; Ball, 2003; Rizvi \& Lingard, 2010). Governments have not followed a single "market formula", but have rolled out a complex assemblage of reforms of "breath-taking" scope and complexity (Ball, 2003, p. 217). A central pillar of reform has been the state-driven creation of education quasimarkets $^{3}$ (Rose, 1999b; Gewirtz, 2002; Gillborn \& Youdell, 2000; Doherty, 2007; Klenowski, 2009). As Rose (1999b) argues, buoyed by beliefs that "the state" is an inefficient mechanism for productivity, most Western governments have engaged in concerted attempts "to create markets and quasi-

2 In my doctoral thesis, I analysed contemporary norms of education governance in Australia and suggested there are four central features of advanced liberalism: markets; freedom; the neo-social; and community (see Savage, 2012).

3 Education markets are most accurately described as 'quasi' due to the strong government regulation they require in order to function (Rose, 1999b; Gillborn \& Youdell, 2000). Schools, therefore, do not operate in a 'free market', as governments remain core providers of educational funding, services, policies and regulations. Thus, whilst there is an "appearance of freedom" (Ball, 2003, p. 217) in marketised education systems, regulation is required so governments can continue to shape and coordinate relations amongst market actors and institutions (Rose, 1999b, p. 481). 
markets in zones of activity previously insulated from the demands of competition and the pressures of consumer choice" (p. 483). In Australia, the quasi-marketisation of primary and secondary education has been achieved through a series of related measures, including, but not limited to: devolved forms of governance that see schools increasingly responsible for self-management, marketing and "client" recruitment (Marginson, 1997; Kenway \& Bullen, 2001; Tsolidis, 2006); an increased emphasis on performance rankings on standardised and high-stake testing (Thomson, 1997; Teese \& Polesel, 2003); the increased specialisation and vocationalisation of school curriculums in relation to economic needs (Teese, 2000; Teese \& Polesel, 2003); the opening up of schools to corporate sponsorship and partnerships (Marginson, 1997; Kenway \& Bullen, 2001); increased funding to state-subsidised full-fee-paying private schools, towards which there has been a steady drift amongst the more socially privileged (Teese, 2000; Vickers, 2005); the national publication and ranking of school performance data through the My School website ${ }^{4}$; and federal government plans to introduce a performance-based pay model from $2014^{5}$. Through instituting these reforms, Australian governments have borrowed heavily from England and the USA, despite research that highlights the deleterious effects of market governance on government schools and the lives of educators and young people in them (Lingard, 2010; Rizvi \& Lingard, 2010).

Quasi-markets are rationalised by governments and policy-makers as solutions to a wide range of educational problems and are variously described as mechanisms for improving student learning outcomes, inspiring productive competition between schools, raising standards, increasing school and teacher accountability, and improving the wider efficacy of systems (Doherty, 2007, Klenowski, 2009; Campbell, Proctor \& Sherrington, 2009). Quasi-markets are also promoted as a means for nourishing parental choice and increasing the capacities of schools to tailor provision to local needs. In Australian government secondary school systems, for example, parents (and

4 My School was launched in January 2010 by the Australian Curriculum, Assessment and Reporting Authority (ACARA). My School provides information about individual Australian schools, including literacy and numeracy data based on results in standardised National Assessment Program Literacy and Numeracy (NAPLAN) tests. See: www.myschool.edu.au

5 The federal ALP government has promised to pay an $\$ 8000$ yearly reward bonus to "one in ten, or about 25,000 of the best classroom teachers" in Australia, based on a yet to be established performance management system. The ALP has said it will develop a nationally consistent, transparent and equitable performance management system, called the 'Australian Teacher Performance Management Principles and Procedures', so the best performing teachers can be identified and rewarded. For more information, see: www.alp.org.au/agenda/school-reform/performance-pay/ 
to a lesser extent, students) are positioned as responsible choosers, capable of being able to self-manage and make informed and wise decisions from a market of increasingly specialised providers (Campbell, Proctor \& Sherrington, 2009). Quasi-markets rest, in this sense, upon "a distinct conception of the human actor" as a self-choosing "entrepreneur of his or herself, striving to maximise his or her own human capital by choices which are, as it were, investments for the purpose of the capitalization of one's own existence" (Rose, 1999b, p. 483). Education providers, in turn, are supposed to be flexible, adaptive and capable of innovating in response to consumer demands. In states like Victoria and Queensland, for example, many schools in higher socio-economic areas choose to only offer academic (universityoriented) senior school pathways, rationalising these choices on the basis of user-demand (Teese \& Polesel, 2003; Savage 2012). In contrast, vocational pathways in the senior years are typically concentrated in lower socio-economic areas (Teese, 2000; Polesel, 2008). There is also a new breed of specialist schools emerging, which provide senior school pathways linked to specific local industry areas. In Queensland, for example, the Department of Education and Training has developed a 'Gateway to Industry Schools Program', which links schools with local industry partners to develop industry-focussed pathways. The project has developed schools such as Aviation High in Brisbane, located close to the Brisbane Airport, which has designed an aerospace-targeted curriculum in association with major corporations such as Boeing and Aviation Australia. School-industry partnerships are also being encouraged in the state of Victoria, where the Victorian Curriculum and Assessment Authority is piloting industry-themed programs which partner schools and corporations in order to develop curricula in local industry areas with identified skills shortages ${ }^{7}$.

The second feature of advanced liberal governance that underpins market tailoring is a shift towards community governance models. In Australia and England, for example, the mid-1990s onwards have seen an explosion of forms of governance which seek to govern through community (Rose, 1999a/b, 2000; Everingham, 2001; Reddel, 2004; Miller \& Rose, 2008; Savage, 2011; McLeod, 2012). According to Miller and Rose (2008), this community turn is marked by a profound shift "in the ways of thinking and acting that used to be conducted in a "social" language" (p. 88). The political imaginary has thus revised its optic, from a concern with states governing "society", as a singular, towards governing and enabling diverse "communities", in plural (p. 90). Community, as a governable space, has emerged in this

6 For more information on the program, see: http://www.gatewayschools.qld.gov.au/

7 For more information on the pilot, see: http://www.education.vic.gov.au/sensecyouth/delivery/default.htm 
vision as "a new territory for the administration of individual and collective existence" (p. 88). This is evident in a range of reforms instituted over the past two decades by centre-left governments in Australia and the UK, which spatialise problems of government, highlighting specific community zones - such as schools, health institutions, housing commission flats, etc - as spaces that require intervention (McLeod \& Savage, 2010). Community has emerged, therefore, as both the problem and simultaneously the solution for addressing a range of social and economic problems.

Sociological and political analyses of community governance have understood it as endogenous to Third Way variants of advanced liberalism (Rose, 1999a/b, 2000; Everingham, 2001; Reddel, 2004). Community is understood, in this sense, as infused into a larger ensemble of Third Way technologies, especially those concerned with responsibilisation and "neo-social" approaches to governance (Rose, 1999a/b). In Australia, community governance models have infiltrated federal and state education policies via multiple channels. One direct channel has been through policy lobbyist and advisor Tom Bentley, former Director of UK policy think-tank Demos (19992006), who relocated to Australia in 2007 to take the position of Executive Director of Policy and Cabinet in Victoria. Bentley has since been appointed Deputy Chief of Staff to current Australian Prime Minister Julia Gillard. In the global policy field, Bentley has been a strong advocate of network and community approaches to governance and has vocally promoted market tailoring and personalisation (see Peters, 2010). Bentley and Wilsdon (2003), for example, argue that in a market society, public institutions should be flexible, adaptive and able to tailor services to the needs of individual citizens and communities. What is required, they argue, is an "adaptive state" that offers citizens "'choice', 'diversity', 'flexibility' and local 'responsiveness" (p. 15). Public services, therefore, must "meet personal needs" (p. 16), which means "far more than being able to choose between different service suppliers", but "requires services to be actively shaped in response to individual profiles (p. 22, italics added).

In Australia, education policies that encourage schools to tailor provision to local markets are increasingly prolific. In February 2012, for example, the Council of Australian Governments (COAG) signed the National Partnership Agreement on Empowering Local Schools (COAG 2012), which commits Australian state and territory governments to increase the local decision making capabilities of school managers and is supported by federal funding of $\$ 475.5$ million over the next seven years. The agreement is underpinned by Australian and international research which suggests devolved governance models increase the capacities of schools to adapt and tailor management and provision, promote locally responsive forms of innovation, and 
allow management greater flexibility over matters of school finances, staff and infrastructure management and curriculum (see Barrera-Osorio et al., 2009; Caldwell, 2009; World Bank, 2007). In Victoria, the current Liberal state government is taking a particularly strong approach to the promotion of market tailoring and devolution. The Victorian Minister for Education, Martin Dixon, for example, recently outlined a reform vision for Victorian schools which draws heavily upon market-based approaches to governance and names "choice", "local decision-making" and "school-community integration" as the three core principles for reform (Dixon, 2011). Dixon said the government is committed to building a "high quality and diverse government education system" that will "respond to the choices made by students and their parents" (p. 9). The ability for schools to make locally informed decisions and adapt to user-demand is, Dixon said, a "non-negotiable" (p. 10) principle for reform. Linked to the Empowering Local Schools partnership, the Victorian government has also made available 'Specialisation Grants", which "will provide the opportunity for government schools to specialise in a curriculum field of their choice" and "allow school communities to pursue their own unique goals" (DEEWR, 2012, p. 2). Market tailoring, it seems, has taken a firm hold of the Australian political imaginary.

\section{Market Tailoring in Practice}

Whilst there is a body of (largely pro-market) research driving market tailoring agendas in policy, there is a lack of critical sociological research which has examined market tailoring in practice. Important questions need to be asked, such as: How are policy rationalities of market tailoring understood and taken up by school managers and educators in different schools? To what extent do different schools flexibly tailor and adapt in response to the needs and desires of individuals in the communities in which they are embedded? In short, what does it mean to turn policy rationalities of market tailoring into tangible and governable practices and what are the implications of doing so?

This paper will begin to explore these questions by focussing on fieldwork from a one-year ethnographic research project conducted in two government secondary schools in the Australian city of Melbourne: Bridgeway High and Clapton High. The two schools provide for a useful comparison of market tailoring in practice, as whilst they are located just eight kilometres apart

8 At this stage, only preliminary information is available on these grants. See: http:// www.education.vic.gov.au/about/directions/nationalpartnerships/empoweringlocalsch.htm 
in Melbourne's suburban southeast, they are in socially and economically disparate communities. Bridgeway, for example, is nestled in a suburban oasis of sorts, home to big houses with lush gardens, quiet streets, high employment and a range of good reputation and tertiary-oriented schools. Clapton, located on the southeast side of the M1 arterial freeway, is in an area cited by Victorian police as a hub for gang and racial violence, with high levels of social housing, unemployment and a series of vocationallyoriented schools ${ }^{9}$. According to socio-economic data from the federal Index of Community Socio-Educational Advantage (ICSEA), Bridgeway is one of the most advantaged schools in the state, with $79 \%$ of students and families in the 'Top' socio-economic quartile and only $1 \%$ in the 'Bottom', compared with Clapton which has 3\% in the 'Top' and 32\% in the 'Bottom'10. Academic achievement also differs considerably between the schools, with Bridgeway regularly named in the popular media as one of the top Victorian government schools for its tertiary entrance rankings and above average performance in the National Assessment Program Literacy and Numeracy (NAPLAN) tests ${ }^{11}$. Bridgeway prides itself on its exemplary academic success and offers only the tertiary-oriented Victorian Certificate of Education (VCE) in the senior years. In contrast, Clapton does not enjoy the same tertiary ranking successes, achieves below the national average on several NAPLAN indicators and offers a range of academic and vocational pathways.

By focussing on these schools, one of the broader purposes of my research was to understand how evolving forms of market governance in education bond with the realm of community (Savage, 2012). My analytical lens was thus macro and micro, examining the broader policy ecology of market governance (political imaginaries, rationalities and technologies) and how these

9 My comments here about gang and racial violence in the Clapton area are based on extensive media coverage on such issues that the area has received in Melbourne media. Issues of gangs, violence and young people's safety in the Clapton area are also discussed in the Rights of Passage report, published by the Victorian Equal Opportunity and Human Rights Commission (VEOHRC, 2008).

10 These values are based on 2009 data, the year in which research was undertaken. Reportage of the ICSEA involves breaking down student population data for each school in Australia into four quarters (Top, Bottom and two 'Middle Quarters'). According to the ICSEA Technical Paper 2009: "It shows the proportion of educationally advantaged or disadvantaged students in the school compared with the spread of students across Australia. For example, if a school was exactly representative of the range of students across Australia, the quarter percentages would all be 25\%" (ACARA, 2009, 8). More information about the ICSEA is available on the My School website: www.myschool. edu.au.

${ }^{11}$ NAPLAN tests students in Years 3, 5, 7 and 9 in government and non-government schools across Australia. Individual school NAPLAN results are available and can be compared online at the My School website (see web-link in previous note). 
market forces were understood and enacted in two very different schools. My interest in local manifestations of market governance lent itself naturally to market tailoring and I investigated this concept from a variety of angles, including the tailoring of curriculum provision and practices associated with equity and inclusion ${ }^{12}$. In this paper, I focus specifically on marketing practices by examining the extent to which each school tailored its marketing in response to the perceived needs and desires of its local community. In doing so, I feature fieldwork data from interviews with school managers and educators, during which I asked them to reflect upon the images their school sold through its marketing materials, and the extent to which they felt these images were tailored to the local market.

To begin, it is important to note that Bridgeway and Clapton were heavily engaged in the kinds of marketing practices and performances now required of government schools in competitive quasi-markets (see Symes, 1998; Kenway \& Bullen, 2001; Tsolidis, 2006; Wilkins, 2012). From my first day in the field, it was clear the "brand essence" (Klein, 2001, p. 7) of each school was carefully considered and governed, and expressed through multiple avenues including snazzy school reception areas, glossy brochures, professionally produced websites, and elaborate school tours. It was not difficult, therefore, to get a taste for the particular 'product' each school offered and how each deployed seductive visual imagery in the hope of distinguishing itself relative to others "in a crowded space of choice" (Wilkins, 2012, p. 75). The marketisation of education has produced, in this sense, "a visually mediated field of choice" (Wilkins, 2012, p. 70), in which schools find themselves "trading in imagery and perception" (Savage, 2012, p. 114) to manage public impressions.

It was also clear that the notion of government schools as competitive entities in a hierarchical quasi-market was no alien concept to the educators I interviewed. Instead, as Zoey, a Bridgeway English teacher in her early-20s suggested, imagining education in market terms felt natural, reflecting "the way people think about education now". Or, as Marion, an English teacher at Clapton with over 30 years experience, put it:

'Market, market, market' is the basic formula now for schools isn't it? The kind of grand plan, like the bible, you know, for modern schools (Marion, English Teacher, CT).

Educators also used terms like product, hierarchy, clientele and market position. To me, their frequent evocation of market metaphors and terminol-

${ }^{12}$ For a discussion of 'tailored equities' in the education market, see Savage (2013, forthcoming). 
ogy was a powerful indicator of the normalisation of market rationalities in schools. Their familiarity with the market also meant it was relatively easy to talk with educators about the concept of market tailoring. In fact, several educators had strong opinions on this policy trend and reflected in both positive and negative terms on its effects in schools.

Without exception, all the educators I interviewed agreed that the needs, desires and aspirations of local parents and students had a bearing on their school's marketing. Educators at both schools were unanimous, therefore, in the view that their school tailored its marketing to the local community.

Bridgeway, for example, promoted itself as a highly competitive and academically rigorous school, with an outstanding record of achievement. Bridgeway's prospectus was an impressive looking glossy document, felt nice and heavy in the hand, and read more like a brochure for a luxury car than a school. The prospectus painted an impressive portrait of academic excellence, featuring peak Australian Tertiary Admission Ranking (ATAR) data and profiling the school's academic crème de la crème via interviews with its highest-performing students from the previous year. Reflecting on the prospectus and other marketing materials, Bridgeway educators said the emphasis on being an excellent academic school was the result of management carefully considering the desires of its typically privileged parent clientele. This was well illustrated a few months into fieldwork, when Bridgeway's Principal instituted a series of brainstorming sessions designed to engage staff in re-imagining and re-branding the school. Geoff, the school's Deputy Principal, said the sessions were set-up to "consider the needs of the type of clients this school attracts and the kind of desires of those parents". From these sessions emerged a consensus that Bridgeway parents were "middle class parents who seek an academic school for their children" (Shane, Senior School Coordinator, BW). Other Bridgeway educators said:

Everyone, all the teachers came up with this idea that we're 'an academic school'... thinking about what parents want... we were all like 'Yes it's the academic! The academic! University, ATAR scores!'. You see parents here are an incredibly active force... the principal was very keen to get our view on what they might want us to be (Desley, Art Teacher, BW).

It showed me a lot about parents influencing schools... the idea of being academic is, at the end of the day, about marketing strategies. It's about looking at the clientele, the parents, the type of parents we get and seeing that putting ourselves out there as being academic is very important (Vicky, Drama Teacher, BW). 
Parents here are unwavering with the academic. It's astonishing really. It's like 'my son is going to an academic school! My son or daughter is going to university!', so it's no surprise I'd say that the marketing sticks so solidly to that line (Zoey, English Teacher, BW).

When I started talking to Bridgeway educators about the brand power of the academic school, I noticed a strong coherence in terms of what 'being academic' was imagined to mean. For example, when describing academic excellence, educators invariably spoke about student performance on NAPLAN tests or in terms of ATARs and university acceptance rates. Shane said the main reason Bridgeway foregrounded these indicators in its marketing was due to their allure to local parents:

We are under no false illusions... we are operating in a market with a particular kind of middle-class parent clientele, who want certain things out of school. They care about ATAR scores and grades, about university, they read up on NAPLAN, PISA, and they look at stats about university entry... with marketing, it's not rocket science around here, you sell the idea of the school as academic (Shane, Senior School Coordinator, BW).

Whilst historically, there is nothing new about the privileging of academic subjects and successes as markers of excellence in secondary schools (Ball, 1981; Goodson, 1997; Teese \& Polesel, 2003), the above comments suggest market governance has seen 'the academic' take on a new governmental role, with schools like Bridgeway seeking to tap into the desires of parents by tightening their market image in line with very specific indicators. Here, a new role has emerged for political technologies like PISA and NAPLAN, which appear to govern and normalise meanings of academic excellence and reduce possibilities for what is considered valuable in the broader community.

In addition to its focus on academic excellence, Bridgeway could also be seen acting private by emulating images of privilege and exclusivity typically associated with the marketing of elite full-fee-paying private schools. The school's website and prospectus, for example, depict spacious and modern looking facilities, with 'tied and blasered' students engaged in exciting learning pursuits such as robotics and art. The prospectus only features images of the new modern buildings on campus, even though the reality of Bridgeway is a collection of ill-matched buildings and dour looking portables, built at various stages since the school's establishment in the early 1960s.

Educators at Bridgeway were highly sceptical of this marketing approach, 
which they described as "taking it too far" (Shane, Senior School Coordinator, BW), being "all about the image" (Vicky, Drama Teacher, BW) and as "an obsession with being like a private school" (Zoey, English Teacher, BW). When I asked educators why the school portrayed a private school image, they invariably referred to the influence of parents in the local area. Vicky, for example, said:

Trust me... the parents around here, they might not always say it straight out, but what they really what is to send their kids to a private school... but a lot of them can't afford it... so the school it sells this private image [laughs] almost I say sometimes so that the parents who want that exclusive experience, who want to feel their kids are that little bit better than others, can fool themselves into thinking they've got a private school without having to pay for one (Vicky, Drama Teacher, BW).

Zoey made similar comments, saying "Bridgeway parents are your private school aspirationals" and "the school's very keen on selling that hope". Bridgeway's marketing, in this sense, seemed to operate as a kind of imaginative panacea, allowing parents to buy into a private school lifestyle which they desire but cannot afford.

At Clapton, staff members also said there was a strong relationship between the school's marketing and the needs and desires of local parents and students. Distinct from Bridgeway, however, this was almost exclusively the case with regards to its marketing of inclusion, caring and safety. Clapton's marketing materials, for example, foregrounded images of the school as a caring, safe and inclusive environment in which students can strive towards personalised learning outcomes. Whilst Clapton promoted itself as academically promising, discourses of academic excellence were expressed in softer tones. Clapton's prospectus, for example, emphasised a focus on 'maximising the potential' of students, however, this was framed in a more holistic sense, in terms of a 'whole-person approach' to learning, a 'supportive and safe learning environment', and a 'broad and engaging curriculum' that offers academic and vocational senior school pathways.

Educators at Clapton said the school's choice to market itself in this way was directly related to its positioning in a low socioeconomic area and the need to reassure parents that their children would be safe from negative influences such as gangs and violence. As Marion said:

I suspect it's a purposeful strategy... historically this school might have been seen, or is seen, to have a bad reputation... it's an area of low SES and all the social problems ... I assume 
this is management's thinking, parents here would worry about how disciplined schools are, about whether their son or daughter would be safe at school... so in an area like this they look for those signs that say 'we're inviting, we'll look after little Johnny' or whatever (Marion, English Teacher, CT).

Michael, Clapton's Middle School Coordinator, made similar comments, suggesting the school's positioning in a relatively disadvantaged community meant it needed to foreground a commitment to inclusion and provide parents with "those signs" that tell them the school is safe and caring:

Michael If you're talking about what parents here want to see... one of the main things for us is to get across that view... that compared to other schools around here, your son or daughter is going to be much better looked after ... when you walk around the local area here, you know, parents are pretty wised up to what goes on, they're hearing things in the media, maybe about a stabbing or a hit and run like you saw in the media last week, then so you think about school and you think, well I need to be sure those influences aren't going to run into the schools.

INT So Clapton really tries to highlight those things in its marketing?

Michael Yes, we definitely do.

\section{Tailoring against the Community? Clapton's 'new' Marketing Direction...}

Differences in the marketing messages foregrounded by Bridgeway and Clapton suggest the rationalities of market tailoring operate as intended in policy, with different schools, in different communities, adapting differently to local markets. We see, therefore, at the level of marketing, evidence of what Bentley and Wilsdon (2003) term "the adaptive state" (p. 15), with public services shaping their design and focus in response to unique local needs.

During the course of my year at Clapton, however, a range of contradictory trends began to emerge, suggesting Clapton was actively steering its marketing in a different direction and attempting to reconstitute both itself 
and its market in ways that tailored against the local community. There was a growing sense, for example, that unlike schools like Bridgeway, Clapton lacked an effective market niche. According to Michael, for example, Clapton's management team was worried the school was not different enough in the local market and needed to work harder to define, build and improve the school's reputation: to put it on the map. Michael said the school's current branding - as a safe and inclusive community - was not very competitive and the school lacked a clear message. Six months after the interview excerpt at the end of the previous section, for example, Michael said management had "clocked onto this idea of the academic school" and were beginning to "brand the school as an academic school and as a more highachieving option than other schools in the area". Marion made similar comments about Clapton's emerging marketing developments:

This school is very aware of trying to change its status, to define itself away from what, well, what is seen to be an area in which your average school has a bad rep, maybe as a poor school in a poor area or one that is more vocational or is for the working class parents ... she [the principal] I believe, is wanting to see us as a school that appeals to a different kind of parent from maybe what might be the norm around here (Marion, English Teacher, $C T)$.

Marion also said that management was seeking to revise the school's current academic and vocational curriculum provision, by cutting down the number of senior-school vocational subjects and by encouraging students to pursue an academic pathway.

These evolutions in marketing and provision suggest that despite being located in very different communities, Clapton was starting to move in the same direction as Bridgeway, animated by normative fields of judgement around the brand of the excellent academic school. Marion's comments also reveal behind the scenes factors at Clapton which imbricate narratives of class identity with marketing language and practices. As Marion suggests, re-orienting marketing towards 'the academic' is partly about trying to appeal to "a different kind of parent" from "the norm around here". In other words, it is about defining Clapton against "poor", "vocational" or "workingclass" schools in the area.

When I asked Marion to tell me more about this 'different kind' of parent and how it fitted into future shifts towards marketing academic excellence, a range of ideas emerged. To begin, Marion said the school was indeed moving upwards in terms of its socio-economic profile, which was changing the 
expectations parents placed on the school. In other words, the school had to appeal to a different audience:

Maybe ten years ago your demographic was very working class... very much catering for your Greek or Italian families who wanted kids to get trades, especially the boys... but the last five years, that's all changed... even though we still cater for many very poor families, there is this new breed, richer families moving into the area because they can't afford houses closer in [to the city] (Marion, English Teacher, CT).

Michael made a similar comment about changing local demographics:

Things are changing... the new generation are set up with different aspirations... even five or ten years ago, you wouldn't have got nearly anyone saying 'university', but now it's basically 'university! university!' for them (Michael, Middle School Coordinator, CT).

Michael also said that whilst Clapton did not have a stellar history of academic success, these indicators were nevertheless central to how these "new parents' judged schools. If the school wanted to be appealing, therefore, it had to foreground commitments to being academic:

We're seeing the [marketing] focus needs to be more on the academic, the scores and the ATARs especially. We have parents now who want students coming here and have hopes of them studying at the University of Melbourne, and becoming lawyers and doctors, and the first question they ask is 'What were your ATAR scores last year? Which universities did students make it into?' (Michael, Middle School Coordinator, CT).

In light of these comments, it is unsurprising that Clapton's management had clocked onto the idea of the academic school, thus seeking to re-orient its brand image and tap into the new aspirations of the local market. From this angle, Clapton might indeed be tailoring its marketing. In other words, changing local demographics mean changing 'user-demand' and result in a broader re-imagining of the 'type' of school Clapton is.

However, despite its "new breed" of families, the Clapton community remains significantly disadvantaged and, as Marion suggested, part of embracing the brand power of the academic school was also about transforming its status and demarcating it from the "norm" of the local community. In other words, whilst demographics might be changing, there was equally a sense that the 
school was trying to re-brand itself in a way that draws upon classed narratives of academic aspiration to define itself against elements of its local community. This supports the research of Gewirtz (2002), who cites growing tensions in comprehensive schools in England that are inculcated into a market structure and are abandoning a "caring ethos", values of "universalism" and "integrationist" practices, for a more marketable "academic ethos", values of "differentiation" and "exclusivist" practices (p. 54). Gewirtz argues that these schools are increasingly displacing responsibility for lower socioeconomic students, who are seen as liabilities and market risks, in favour attracting academically aspirational and middle-class parents and students who are seen to have greater market value (p. 60). At Clapton, therefore, becoming an excellent academic school might be read as part of a project of re-classing (or up-classing) away from 'lower-class' options in the local area. Of course, the idea of re-branding the school away from the community runs directly counter to policy rationalities of tailoring and personalisation, which suggest market governance should enable "greater customisation ... and targeting of public services in accordance with the different and specific needs of various client or constituent groups" (Peters, 2010, p. 364). Instead, we see a glossing over of local differences as diverse schools realise the power of marketing a very similar academic product.

Further evidence of Clapton's desire to market and govern itself away from its local community emerged when Michael started talking about the significant energies being placed by management into luring full-fee paying international students through international marketing. According to Michael, Clapton had not only been successful in attracting more international students over the past five years, but was ramping up its efforts. For Michael, international students, the majority of whom he said were from "wealthy Chinese backgrounds", were an asset, not only because of the money they brought the school ${ }^{13}$, but because they brought with them an academic dynamic:

... the internationals have really added something to this school... the international students add a new dynamic... it's about results, and there's a lot of pressure on the kids from parents. 'I wanna see the results!'... It's just about academic performance

13 The DEECD's International Student Program was established in the mid-1990s as part of a suite of market reforms in education. This is a lucrative market for Victorian government secondary schools, with each international senior secondary student paying a set annual fee of $\$ 13,640$ Australian dollars (as legislated under the Education and Training Reform Act 2006). For more information, see: http://www.eduweb.vic.gov. au/edulibrary/public/commrel/policy/ministerialorder512.pdf 
with the international parents, all they want to know is whether their kid is going to get the grades to get into Melbourne Uni ... I know the international coordinator very well and she gets that all the time. 'Melbourne Uni! Melbourne Uni!'.. It's a stereotype but true, the Asian families... value the academic and push hard with the academic ... and the students do tend to achieve highly (Michael, Middle School Coordinator, CT).

As well as raising the school's academic profile, international recruitment and marketing had taken on new importance for Clapton because four nearby schools were amalgamating into a specialist Maths, Science and Language school, which the local newspaper had described as the dawn of a "super school"14. Michael said management had "serious concerns" about this new school, mainly because of increased competition and its potential to sap local talent. To build Clapton's academic profile, therefore, it was important to look beyond the local community and import talent from mainland China. The important thing, Michael said, was locking in academicallyinclined Chinese students before other schools could get to them (as Victorian student VISA requirements mean it is difficult for students to switch between providers once they have enrolled at a host institution). Of course, to attract these 'academic students', the school had to brand itself as an 'academic school', even if it lacked the accolades of schools like Bridgeway. As such, when I asked Michael what kind of message the school sold on its marketing tours to China, he said bluntly: "we push the academic... we sell the academic".

Again, rather than tailoring to local specificities and branding itself in ways which reflect the apparent needs or desires of the local community, Clapton can be seen engaging in marketing performances which tap into normative fields of judgement concerning 'academic' value and success. In fact, these norms transcend local space to an extent, forming part of an emerging 'global imaginary' (Steger, 2008; Rizvi \& Lingard, 2010) of education in which it is taken for granted that a hierarchy of schools exists and that 'the best' schools are 'academic'. In this context, Clapton is not only trying to reconstitute itself, but also its market by opening its reach beyond its apparently downmarket local community. Rather than schools like Clapton being valuable and adaptable public resources for local families and parents, certain kinds of families and parents now represent valuable resources and investments for schools like Clapton (see also, Gewirtz, 2002). This turns the classic policy notion of 'school choice' (understood in terms of parents/students choosing schools) on its head, because here we see the converse, with

14 To protect school anonymity, I have not included the media source for this quote. 
Clapton doing the choosing. In other words, in a market system, parents and students are recast as capital to be assessed and lured based on their financial and academic worth. This is not to suggest schools like Clapton are no longer valuable to families and students, but that in a market climate, schools have a vested interest in seeking out valuable clients, just as clients have an interest in seeking out valuable schools.

In order to better market itself as 'academic', Michael said management was also ramping up its attention to the kinds of images Clapton portrayed and to "the look and style of our marketing". When I asked Michael exactly what this meant, he spoke of needing to re-vamp the school's website and prospectus and said, "to be honest, I'd say we're putting out there a more private school image". This was supported by Sarah, an English teacher at Clapton, who said she suspected management had been "stealing ideas from private school websites". Marion made a similar comment, saying the school's management "is waylaid" by the idea that Clapton "should come off looking like a private school". When I mentioned Sarah and Marion's comments to Michael, he said Clapton has "a definite image problem", adding:

We're the kind of school that wants to be a BMW... because of this academic focus, like a private school, with the blasers and the positions and the marketing, but we're not... you know, you want to be a BMW, you want to be prestigious, but you're a Honda, or a Toyota, because all the families drive them! (Michael, Middle School Coordinator, CT).

This comment underlines tensions between Clapton's market image and its reality. Strong here are narratives of hierarchy, status and yearnings for prestige. Whilst Clapton engages in certain market performances in the hope of being seen as the BMW of schools, it is really the type of car "all the families drive". For Michael, I got the sense that being average and catering for "all families" was a bit of a disappointment.

Overall, the idea that Bridgeway and Clapton were both attempting to 'act private' suggests that much like the excellent academic school, the image of schools as private and exclusive has significant brand value. Regardless of the existing communities in which each school is located, therefore, both could be seen performing a particular 'imagined community' (Anderson, 1983), which conflates educational value with classed narratives of privilege and distinction. These classed imaginations serve to govern the marketing performances of each school, stamping out potential differences and reducing possibilities for each to carve a distinctive market niche. Again, rather than adapting to diverse communities, we see instead the evocation of classed values and ideals which rely fundamentally on exclusion and sug- 
gest each school wants to cater for the same kind of young person and community. Ironically, of course, the extent to which acting private is an effective means of creating market distinctions is highly questionable when very different schools in very different communities use the same strategies.

\section{The Paradoxes of Market Tailoring: Being Different and the Same?}

Towards the end of my year in the field, I had a long conversation with Geoff at Bridgeway, during which I suggested that market images of academic excellence, private-ness and exclusivity were increasingly normalised in Victorian schools. Geoff reacted strongly to this idea, slapping his hands loudly on his thighs and stating emphatically that one of the main effects of market governance is that it has "tightened up" schooling. When I asked Geoff to explain, he said, regrettably, that management teams in previously diverse schools are now re-aligning marketing, curriculum provision and a range of other functions in line with the pursuit of very similar aims:

I've really noticed it ... there's been very substantially a strong shift in the last decade especially ... the actual point of school now, we're all pretty much, whether you're in your poor rural school or your elite inner eastern suburbs private school, we're all going for the this type of numbers, ATAR-score type of academic, because that's what matters now ... really that is the pinnacle we're all working towards ... at these network meetings, you talk to these other principals, etcetera, and it's the same talk (Geoff, Deputy Principal, BW).

Geoff added that "the private school thing" is directly linked to the academic, because "it's those schools that are seen as academically best... so it's them you want to look like, don't you?". When I suggested to Geoff that his comments were in tension with earlier interviews in which he and other Bridgeway educators had rationalised the school's marketing as a tailoring response to its 'middle class' community, Geoff maintained that it was indeed the case that Bridgeway's marketing was tailored in this way. A few minutes later, however, Geoff again emphasised the point that: "all schools are now promoting this image". So, Bridgeway is ostensibly tailoring to its local community, but at the same time, "all schools" are apparently marketing the same way.

Geoff's reflections serve well to illustrate broader tensions at Bridgeway and Clapton, which underline the inherent contradictions that emerge when 
market tailoring is attempted in a competitive and hierarchical quasi-market in which 'brand value' is a normative and rigid force. In other words, despite educators in both schools maintaining that their school was actively tailoring in response to the needs, desires and aspirations of local parents and students, it was clear that both schools were also attempting to market in very similar ways by promoting normative images associated with academic excellence and by emulating the marketing practices of exclusive private schools. As Geoff put it, schools which cater for diverse communities now find their compasses pointing in the same direction: with school managers engaged "in the same talk", all heading towards the same "pinnacle". It is difficult, in this context, to engage in marketing practices that transcend these powerful market norms.

The policy desire for schools to tailor education to the needs of local markets thus appears somewhat paradoxical to market pressures on schools to perform in line with normative images of 'the good school': that is, images based on a rigid and numbers-driven form of academic excellence and on classed imaginations which conflate quality with notions of private-ness and exclusivity. Rather facilitating market responsiveness, local diversity, or producing a heterogeneous ecology of schools, these normative images have regulatory effects, white-washing local differences and implicating both schools in normalised practices and performativities. The erasure of local specificity was exacerbated at Clapton, where embracing the brand power of the academically excellent and private-like school was partly about transforming the status of the school and defining it against elements of its disadvantaged local community. Rather than pliability to community of the kind promoted by policy think-tanks such as Demos (see Bentley \& Wilsdon, 2003), we see instead an abrogation of community when 'the local' fails to measure up. The irony here, of course, is that both schools were attempting to imagine and govern themselves in line with this normative imagination in order to be perceived as better, distinct or different relative to others in the local market. There is, in this sense, a heightened awareness of the importance of the local community, but at the same time, a sense that the needs and desires of the local community are of minimal influence compared to the need to perform in line with system-wide indicators of market value.

Ultimately, a chasm appears to exist between policy rationalities and the realities of governing schools in an education market. Put differently, marketisation produces effects which run counter to the aims of marketisation. Schools are caught, in this context, between paradoxical demands, requiring them to be simultaneously different and the same. 


\section{References}

ACARA. (2009). ICSEA technical paper 2009. Sydney: Australian Curriculum, Assessment and Reporting Authority.

Anderson, B. (1983). Imagined communities: Reflections on the origin and spread of nationalism. London: Verso.

Ball, S. J. (1981). Beachside comprehensive: A case-study of secondary schooling. Cambridge: Cambridge University Press.

Ball, S. J. (2003b). The teacher's soul and the terrors of performativity. Journal of Education Policy, 18(2), 215-228.

Ball, S. J. (2006). The education debate: Policy and politics in the twenty-first century. Bristol: The Policy Press

Ball, S. J. (2012). Global education Inc: New policy networks and the neo-liberal imaginary. London: Routledge.

Barrera-Osorio, F., Fasih, T., Patrinos, H., \& Santibanez, L. (2009). Decentralized decision-making in schools: The theory and evidence on school-based management. Washington: The World Bank.

Bentley, T., \& J. Wilsdon. (2003). The Adaptive state: Strategies for personalising the public realm. London: Demos.

Campbell, C., Proctor, H., \& Sherington, G. (2009). School choice: How parents negotiate the new school market in Australia. Crows Nest: Allen \& Unwin.

Caldwell, B. J. (2009). Centralisation and decentralisation in education: A new dimension on policy. In J. Zajda, \& D. T. Gamage (Eds.), Decentralisation, schoolbased management, and quality (pp. 53-66). Dordrecht: Springer.

COAG (2012) National partnership agreement on empowering local schools. Canberra: Council of Australian Governments.

Dean, M. (1999). Governmentality: Power and rule in modern society (1st ed.). London: Sage.

Dean, M. (2010). Governmentality: Power and rule in modern society (2nd ed.). London: Sage.

DEEWR. (2012). Making every school a great school: Empowering local schools (Victorian Fact Sheet). Australian Government: Department of Education, Employment and Workplace Relations.

Dixon, M. (2011). Victoria as a learning community: Extended special lecture - Melbourne graduate school of education. Melbourne: Department of Education and Early Childhood Development.

Doherty, R. A. (2007). Education, neoliberalism and the consumer citizen: After the golden age of egalitarian reform. Critical Studies in Education, 48(2), 269-288.

Everingham, C. (2001). Reconstituting community: Social justice, social order and the politics of community. Australian Journal of Social Issues, 36(2), 105-122.

Foucault, M. (2008). The birth of biopolitics: Lectures at the Collège de France, 19781979. New York: Palgrave Macmillan. 
Gewirtz, S. (2002). The managerial school: Post-welfarism and social justice in education. London: Routledge.

Giddens, A. (1998). The third way: The renewal of social democracy. Cambridge: Polity Press.

Gillborn, D., \& Youdell, D. (2000). Rationing education: Policy, practice, reform and equity. Buckingham: Open University Press.

Goodson, I. (1997). The changing curriculum: Studies in social construction. New York: Peter Lang Publishing.

Kenway, J., \& Bullen, E. (2001). Consuming children: Education-entertainment-advertising. Buckingham: Open University Press.

Klenowski, V. (2009). Public education matters: Reclaiming public education for the common good in a global era. The Australian Educational Researcher, 36(1), 1-25.

Lingard, B. (2010). Policy borrowing, policy learning: Testing times in Australian schooling. Critical Studies in Education, 51(2), 129-147.

Lipman, P. (2011). The new political economy of urban education: Neoliberalism, race, and the right to the city. New York: Routledge.

McLeod, J. (2012). Vulnerability and the neo-liberal youth citizen: A view from Australia. Comparative Education, 48(1), 11-26.

McLeod, J., \& Savage, G. C. (2010). Governing the local: Community, 'vulnerable' youth and democracy. In Re-imagining Public Education: Critical Politics and Democracy symposium at the AERA Annual Meeting, Denver, USA, 2010.

Marginson, S. (1997). Markets in education. St Leonards: Allen \& Unwin.

Miller, P., \& Rose, N. (2008). Governing the present: Administering economic, social and personal life. Cambridge: Polity.

Ong, A. (2006). Neoliberalism as exception: Mutations in citizenship and sovereignty. Durham: Duke University Press.

Peters, M. A. (2010). Practice. In M. A. Peters, S. Marginson \& P. Murphy (Eds.), Imagination: Three models of imagination in the age of the knowledge economy (pp. 363-382). New York: Peter Lang.

Polesel, J. (2008). Democratising the curriculum or training the children of the poor: School- based vocational training in Australia. Journal of Education Policy, 23(6), 615-631.

Reddel, T. (2004). Third way social governance: Where is the State? Australian Journal of Social Issues, 39(2), 129-142.

Rizvi, F., \& Lingard, B. (2010). Globalizing education policy. New York: Routledge.

Rose, N. (1996). Governing "advanced" liberal democracies. In A. Barry, T. Osborne, $\&$ N. Rose (Eds.), Foucault and political reason: Liberalism, neo-liberalism and rationalities of government (pp. 37-64). Chicago: The University of Chicago Press.

Rose, N. (1999a). Powers of freedom: Reframing political thought. Cambridge: Cambridge University Press.

Rose, N. (1999b). Inventiveness in politics. Economy \& Society, 28(3), 467-493. 
Rose, N. (2000). Community, citizenship, and the third way. American Behavioral Scientist, 43(9), 1395-1411.

Savage, G. C. (2011). When worlds collide: Excellent and equitable learning communities? Australia's 'social capitalist' paradox? Journal of Education Policy, 26(1), 33-59.

Savage, G. C. (2012). Imagination, governance, community: Making education, making difference. PhD Thesis: The University of Melbourne.

Savage, G. C. (2013, forthcoming). Tailored equities in the education market: Flexible policies and practices. Discourse: Studies in the Cultural Politics of Education, 34(2).

Steger, M. (2008). The rise of the global imaginary: Political ideologies from the French Revolution to the global war on terror. Oxford: Oxford University Press.

Symes, C. (1998). Education for sale: A semiotic analysis of school prospectuses and other forms of educational marketing. Australian Journal of Education, 42(2), 133-152.

Teese, R. (2000). Academic success and social power: Examinations and inequality. Melbourne: Melbourne University Press.

Teese, R., \& Polesel, J. (2003). Undemocratic schooling: Equity and quality in mass secondary education in Australia. Melbourne: Melbourne University Publishing.

Thomson, P. (1997). Thoroughly modern management and a cruel accounting: The effects of public sector reform on public education. In A. Reid (Ed.), Going public: Education policy and public education in Australia. Canberra: Australian Curriculum Studies Association.

Tsolidis, G. (2006). Youthful imagination: Schooling, subcultures and social justice. New York: Peter Lang.

VEOHRC. (2008). Rights of passage: The experiences of Australian-Sudanese young people. Melbourne: Victorian Equal Opportunity \& Human Rights Commission.

Vickers, M. (2005). In the common good: The need for a new approach to funding Australia's schools. Australian Journal of Education, 49(3), 264-278.

Wilkins, A. (2012). School choice and the commodification of education: A visual approach to school brochures and websites. Critical Social Policy, 32(1), 69-86.

World Bank. 2007. What do we know about School-Based Management? Washington, DC: The World Bank.

\section{Author:}

Glenn C. Savage, PhD.

The University of Melbourne

Melbourne Graduate School of Education

Education Policy and Leadership

Level 7, 100 Leicester Street Carlton

Victoria

3053

Australia

email: gcsavage@unimelb.edu.au 